\title{
Organic Carrot (Daucus carota L.) Production Has an Advantage over Conventional in Quantity as Well as in Quality
}

\author{
Ingrid Bender ${ }^{1, *}$, Liina Edesi ${ }^{2}$, Inga Hiiesalu ${ }^{3}$, Anne Ingver ${ }^{1}$, Tanel Kaart $\left.{ }^{4}{ }^{(}\right)$, Hedi Kaldmäe ${ }^{5}$, \\ Tiina Talve ${ }^{2}$, Ilmar Tamm ${ }^{1}$ and Anne Luik ${ }^{6}$ \\ 1 Department of Jõgeva Plant Breeding, Estonian Crop Research Institute, J. Aamisepa 1, 48309 Jõgeva alevik, \\ Estonia; anne.ingver@etki.ee (A.I.); ilmar.tamm@etki.ee (I.T.) \\ 2 Department of Agrotechnology, Estonian Crop Research Institute Estonian Crop Research Institute, \\ J. Aamisepa 1, 48309 Jõgeva alevik, Estonia; liina.edesi@etki.ee (L.E.); tiina.talve@etki.ee (T.T.) \\ 3 Institute of Ecology and Earth Sciences, University of Tartu, Vanemuise 46, 51003 Tartu, Estonia; \\ inga.hiiesalu@ut.ee \\ 4 Institute of Veterinary Medicine and Animal Sciences, Estonian University of Life Sciences, \\ Fr. Kreutzwaldi 62, 51014 Tartu, Estonia; tanel.kaart@emu.ee \\ 5 Polli Horticultural Research Centre, Estonian University of Life Sciences, Uus 2, 69108 Polli küla, Estonia; \\ hedi.kaldmaee@emu.ee \\ 6 Research Centre of Organic Farming, Estonian University of Life Sciences, Fr. Kreutzwaldi 5, 51014 Tartu, \\ Estonia; anne.luik@emu.ee \\ * Correspondence: ingrid.bender@etki.ee; Tel.: +372-7766909
}

Received: 27 August 2020; Accepted: 16 September 2020; Published: 18 September 2020

\begin{abstract}
Organic production is one of the fastest growing food sectors globally. However, average yield in organic vegetable production is up to $33 \%$ lower than in conventional production. This difference could be due to higher fertilization rates in conventional, compared to organic, farming. We aimed to compare yield and quality characteristics of carrots produced under equal nitrogen fertilization rates over four years in organic and conventional conditions. We found a 14.5\% higher marketable, and $10.0 \%$ lower discarded, yield in the organic compared to the average conventional treatments. In addition, carrots managed organically had $14.1 \%$ lower nitrate and $10.0 \%$ higher vitamin $C$ content than carrots managed conventionally. There were no convincing effects of cultivation system on the nitrogen, total sugar, or dry matter content of carrots. Organically managed carrots were free of pesticide residues, while several residues were found in carrots managed conventionally. Our study reveals that organic management of carrots may exceed that of conventional methods in yield and several quality characteristics, while being free of pesticide residues. Organic fertilizer gave an advantage over mineral fertilizer, when equal rates of nitrogen were used in both production systems.
\end{abstract}

Keywords: carrot; organic and conventional yield; nitrate; vitamin C; total sugars; dry matter; pesticide residues; organic fertilizer

\section{Introduction}

Organic production continues to be one of the fastest growing food sectors globally [1], and is often promoted as a sustainable alternative to conventional agriculture [2]. The organic vegetable market is being largely driven by increased consumer demand for organic food [3-6], as it is perceived to be healthier and safer for the environment $[5,7,8]$. Although the area of organic vegetable production has increased more than six-fold worldwide during recent decades [9], the performance and benefits of organic agriculture need further research. 
It is a general notion that, although organic production reduces environmental impacts due to the restricted use of synthetic fertilizers and pesticides, it often results in lower yields, making the (economic) sustainability of organic farming questionable [10]. The yield gap in horticulture has been shown to vary a lot between experiments comparing organic and conventional systems [7,11-14]. Two global meta-analyses concluded that across all crops the average yield of organic production is $20-25 \%$ lower than conventional production, whereas vegetables can have up to even $33 \%$ lower yields in an organic system $[15,16]$. In addition to lower yields, organic production can have a relatively high yield variability $[2,17]$.

Consumers expect organic food to have a higher nutritional value, while being free of chemical residues [5]. Seufert and Ramankutty [2] concluded in their review that organically produced food in general tends to contain a higher amount of secondary metabolites, vitamins, and various mineral nutrients, but that these results vary greatly between studies. Pesticides on the other hand are potentially toxic to humans, and can have both acute and chronic health effects, depending on the quantity and way in which a person is exposed to them [18]. Pesticides have been applied across the world for almost a century, creating a build-up of adverse pollution in our environment [1]. A recent European-wide study detected pesticide residues in over $80 \%$ of the tested agricultural soils [19]. Therefore, synthetic pesticide residues in vegetables have become a special concern, not only due to potential negative influences on soil microorganisms and human health, but also in terms of consumer expectations [20,21]. According to Seufert and Ramankutty [2] the majority of studies have found that, compared to conventional production, organically produced food, indeed, has reduced contamination from pesticide residues.

Yield and quality of crops depend mainly on the type and applied rates of fertilizers, locality or soil type, and climatic conditions during the year of harvest [22-24]. However, it has been pointed out that studies comparing the yield and quality of organic versus conventional vegetables have often provided inconsistent results, due to methodological problems in experimental design [24-29]. The typical problem is that fertilization rates of the main plant nutrients are higher in conventional than organic crop production [28]. For example, according to Swedish national statistics, for all crops harvested in 2013, the average nitrogen (N) fertilization was $64 \mathrm{~kg} \mathrm{ha}^{-1}$ in organic and $115 \mathrm{~kg} \mathrm{ha}^{-1}$ in conventional production [28]. This problem can be overcome by increasing the addition of organic matter in the organic system, thereby improving soil health and reaching the same levels of nutrients as in the conventional system [29-32]. Kirchmann et al. [33] have stressed that at least three criteria should be followed to ensure correct interpretation of comparative studies of organic vs. conventional production: the initial soil fertility must be similar between plots, ideally only the same type of crop production is compared, and rates of nutrient input to each system must be quantified. By taking the above-mentioned criteria into account, we compared the yield and quality indicators of carrots produced in an organic and in a conventional system, with the same initial soil fertility, and with equal nitrogen fertilization rates.

We hypothesized that: (1) The yield of carrot production does not differ between conventional and organic systems with equal levels of nitrogen fertilization; (2) Organically produced carrots have better quality than conventional carrots in terms of various quality indicators and a lack of pesticide residues.

\section{Materials and Methods}

\subsection{Field Experiment Design}

The study was carried out at the Estonian Crop Research Institute, Jõgeva, Estonia ( $58^{\circ} 76^{\prime} 24^{\prime \prime} \mathrm{N}$, $26^{\circ} 39^{\prime} 76^{\prime \prime}$ E) in the Nemoral climatic zone [34] from 2011 to 2014. Weather conditions during the experimental years are described below (see section weather conditions). The experimental area had been out of intensive use for at least 30 years, and for the last four years had been managed according to organic farming practice (no use of synthetic fertilizers and pesticides). Soil at the site is clay loam classified as Endogleyc Luvisol (FAO 2014) [35]. A pooled topsoil sample was analyzed before the 
establishment of the experiment, and the following results were obtained: $\mathrm{pH}_{\mathrm{HCl}} 6.4, \mathrm{P} 356 \mathrm{mg} \mathrm{kg}^{-1}$, $\mathrm{K} 220 \mathrm{mg} \mathrm{kg}^{-1}$, Ca $2067 \mathrm{mg} \mathrm{kg}^{-1}$, Mg $210 \mathrm{mg} \mathrm{kg}^{-1}$, Cu $4.0 \mathrm{mg} \mathrm{kg}^{-1}$, Mn $117 \mathrm{mg} \mathrm{kg}^{-1}$, B $0.08 \mathrm{mg} \mathrm{kg}^{-1}$, and $\mathrm{C}_{\text {org }} 2.0 \%$. Hence, the nutritional status of the soil was satisfactory and soil acidity favorable for carrot cultivation. No pesticide residues were present in the soil. The trial area was divided into four fields and carrot was grown in a different field with a different precrop each year. The preceding crops before carrot experiments were as follows: barley (Hordeum vulgare L.) in 2011; a mixture of phacelia (Phacelia tanacetifolia Benth.), mustard (Sinapis alba L.), and crimson clover (Trifolium incarnatum L.) in 2012; red clover (Trifolium pratense L.) in 2013 and 2014.

The experimental layout was a randomized complete block design with four experimental plots $(5.0 \mathrm{~m} \times 2.0 \mathrm{~m}$ each) per block, in three replications. In each block, three plots had conventional production treatment (CON5, CON3, and CON1) and one plot had organic treatment (ORG). Conventional production treatments differed in the types of pesticides and number of sprayings during the growing period: CON5 was sprayed five times, receiving two herbicides, the same insecticide twice, and one fungicide; $\mathrm{CON} 3$ was sprayed three times, receiving one of each pesticide; and CON1 was sprayed once, receiving one herbicide (Table 1). The ORG treatment received no pesticides, according to EU regulations on organic production (Council Regulation No. 843/2007).

Table 1. Used synthetic pesticides in treatments, classification by target organisms, and growth stages of carrot [36] when spraying was carried out in the conventional cultivation from 2011 to 2014.

\begin{tabular}{|c|c|c|c|c|c|}
\hline No. & Treatment & Used Pesticides a.s. & Pesticide Category & Application Rates of a.s. & Growth Stages \\
\hline \multirow{5}{*}{5} & \multirow{5}{*}{ CON5 } & aclonifen & herbicide & $2.01 \mathrm{ha}^{-1}$ & 07 \\
\hline & & propaquizafop & herbicide & $1.0 \mathrm{~L} \mathrm{ha}^{-1}$ & 14 \\
\hline & & cypermethrin & insecticide & $0.15 \mathrm{~L} \mathrm{ha}^{-1}$ & 10 and 20 \\
\hline & & chlorothalonil & fungicide & $3.0 \mathrm{~L} \mathrm{ha}^{-1}$ & 44 \\
\hline & & aclonifen & herbicide & $2.0 \mathrm{~L} \mathrm{ha}^{-1}$ & 07 \\
\hline \multirow[t]{2}{*}{3} & \multirow[t]{2}{*}{ CON3 } & cypermethrin & insecticide & $0.15 \mathrm{~L} \mathrm{ha}^{-1}$ & 20 \\
\hline & & chlorothalonil & fungicide & $3.0 \mathrm{~L} \mathrm{ha}^{-1}$ & 44 \\
\hline 1 & CON1 & aclonifen & herbicide & $2.0 \mathrm{~L} \mathrm{ha}^{-1}$ & 07 \\
\hline
\end{tabular}

Synthetic pesticides were applied according to the recommended mean doses to control weeds, insects (carrot psyllid, Trioza viridula Zetterstedt and carrot fly, Psila rosae Fabricius), and diseases (black rot of carrots, Alternaria radicina Meier Drechsler et Eddy). Before sowing, conventional plots were fertilized by applying $1 \mathrm{t} \mathrm{ha}^{-1}$ of Cropcare 8-12-23 ( $\mathrm{N}_{8}, \mathrm{P}_{5}, \mathrm{~K}_{19}$ plus micronutrients), whereas organic plots received $8 \mathrm{tha}^{-1}$ of horse manure bio-compost $\left(\mathrm{N}_{1}, \mathrm{P}_{0.3}, \mathrm{~K}_{0.8}\right.$, plus micronutrients), so that both systems received $80 \mathrm{~kg} \mathrm{~N} \mathrm{ha}^{-1}$. We used a local old middle-ripening orange-colored carrot variety "Jõgeva Nantes" (on the variety list since 1952), which is the only carrot variety of Estonian origin, and well adapted to local conditions and popular among organic growers. Seeds of the carrots were sown at the end of May at a seeding density of 100 seeds $\mathrm{m}^{-1}$. The seeds were sown in a pair of rows, $20 \mathrm{~cm}$ between the rows and $50 \mathrm{~cm}$ between each pair of rows. To control weeds all experimental plots, including the conventional treatment were weeded twice by hand and hoeing.

\subsection{Yield and Chemical Analyses}

The carrots were harvested by hand at the beginning of October in 2011 and 2012, and at the end of September in 2013 and 2014. Two yield fractions, marketable and discarded yield, were quantified in both production systems. Discarded yield consisted mainly of cracked, but also of forked and small roots (diameter $<2 \mathrm{~cm}$ ). A randomly selected sample of marketable yield of $8 \mathrm{~kg}$ was taken from each plot. From this a random $600 \mathrm{~g}$ sample was taken for laboratory analyses the following day. Total sugar content was determined following the modified Bertrand method, as described by Turbas and Oll [37]: the extract was treated with Fehling solution and the $\mathrm{Cu}_{2} \mathrm{O}$ sediment obtained filtered, dissolved in $\mathrm{Fe}_{2}\left(\mathrm{SO}_{4}\right)_{3}$, and the quantity of reducing sugars calculated from the results of titration with $\mathrm{KMnO}_{4}$. Non-reducing sugars were hydrolyzed at $60{ }^{\circ} \mathrm{C}$ with the addition of sulfuric acid before analysis. 
Ascorbic acid (vitamin C) content was determined according to ISO 6557/2:1984, using the modified Tillman method by titration of ascorbic acid with 2.6-dichloroindophenol under acid conditions. Dry matter (DM) content was determined according to EVS-EN 12,145:2000 by determination of loss of mass during drying at $70^{\circ} \mathrm{C}$ in the vacuum oven. Total $\mathrm{N}$ content was determined by the copper catalyst Kjeldahl method, and nitrate content by flow injection analysis, using Fiastar 5000 (ISO 13395).

Residues of the applied pesticides were tested from the carrots (aclonifen, chlorothalonil, cypermethrin and propaquizafop) using a multi-residue QuEChERS method combining gas (aclonifen, chlorothalonil, and cypermethrin) and liquid (propaquizafop) chromatography following the acetonitrile extraction of the sample and clean-up by dispersive solid phase extraction, as described in the European Standard EVS-EN 15,662:2008, and validated according to the requirements of SANCO/10684/2009. One sample of pesticide residues per treatment was analyzed each year, except for CON1 in 2013 and 2014 (were not measured). Testing of carrots in ORG provided an opportunity to state with certainty that these treatments did not contain pesticide residues.

\subsection{Weather Conditions}

Data of air temperatures and precipitation from May to October 2011-2014 were obtained from the closest meteorological station. In summary, monthly average air temperature was higher and the amount of precipitation was lower than the long term averages (LTA) during the growing seasons of 2011 and 2013, whereas the summer of 2011 was extremely dry (Table 2). The vegetation period of 2012 was characterized by higher than LTA precipitation and close to average temperature. Rain was frequent in June on twenty-two days out of thirty. The distribution of precipitation in 2014 was irregular: June and August were wetter, whereas July and September were drier than the LTA.

Table 2. Long-term monthly average of air temperature, sum of precipitation, and deviations from the average.

\begin{tabular}{|c|c|c|c|c|c|c|c|c|c|c|}
\hline \multirow{3}{*}{ Month } & \multicolumn{5}{|c|}{ Temperature $\left({ }^{\circ} \mathrm{C}\right)$} & \multicolumn{5}{|c|}{ Precipitation (mm) } \\
\hline & \multicolumn{6}{|c|}{ Deviation } & \multicolumn{4}{|c|}{ Deviation } \\
\hline & LTA & 2011 & 2012 & 2013 & 2014 & LTA & 2011 & 2012 & 2013 & 2014 \\
\hline May & 10.3 & 0.7 & 1.2 & 4.0 & 1.2 & 50 & -15 & 12 & 33 & 14 \\
\hline June & 14.5 & 3.0 & -1.1 & 3.3 & -1.4 & 69 & -30 & 41 & -31 & 89 \\
\hline July & 16.8 & 3.7 & 1.1 & 0.8 & 2.4 & 79 & -45 & 6 & -44 & -31 \\
\hline August & 15.4 & 0.9 & -0.6 & 1.3 & 1.2 & 89 & -14 & 41 & -19 & 34 \\
\hline September & 10.6 & 2.0 & 1.6 & 0.4 & 1.0 & 66 & -13 & -7 & -34 & -39 \\
\hline October & 5.3 & 1.9 & 0.5 & 1.3 & -0.2 & 66 & 7 & 6 & -8 & -18 \\
\hline
\end{tabular}

LTA = Long term average (1922-2015).

\subsection{Statistical Analyses}

Two-way analysis of variance (ANOVA) was used to determine the effects of treatment and year, and their interactions, on carrot yield and quality parameters. Two different analyses were performed: at first all four treatments (CON5, CON3, CON1, and ORG) were compared, and second an average of the three conventional production treatments (CON-AV) was calculated and only two treatment groups (CON-AV and ORG) were compared. The pairwise differences between treatments within years and overall, as well between years within treatments, were tested with the Tukey-Kramer (HSD) test. These statistical analyses were performed using JMP 5.0.1.2 software SAS, 2002 (SAS Institute, Inc., Cary, NC, USA).

Principal component analysis (PCA) was used to discover the common patterns in carrot yield parameters, and to visualize their dependency on treatment and year. Data were log-transformed and centered before the PCA. Spearman rank correlation analysis was used to assess pairwise relationships between measured carrot yield parameters. PCA and Spearman correlation analyses were conducted in R version 3.5.2, 2018 (R Core Team, Vienna, Austria). 


\section{Results}

\subsection{Yield}

The results of ANOVA showed that the marketable yield and the share of discarded yield were both significantly affected by treatment ( $p=0.012$ and $p=0.023$, respectively) (CON-AV vs. ORG) and year (both $p<0.001$; Table 3). Additionally, discarded yield was significantly affected by the interaction between treatment and year (Trm*Year, $p=0.008)$. Across four trial years the average marketable yield of organic production was significantly higher than CON-AV (14.5\%). In addition, the percent of discarded yield was significantly lower in ORG compared to CON-AV (10.0\%). Generally, marketable yield was higher in ORG compared to CON-AV in all trial years, however, this difference was significant only in 2012. In contrast, the effect of treatment on the share of discarded yield depended on year; in 2011-2013 discarded yield was generally lower in ORG (although significantly so only in 2012), but in 2014 it was lower in CON-AV (although the difference remained non-significant). The hot and extremely dry growth period in 2011 resulted in week germination of seeds, and caused the significantly lowest marketable, and the highest discarded, yields across all four treatments (both $p<0.001)$ (Table S1).

Table 3. Marketable and discarded yield and content of nitrogen, nitrates, vitamin C, sugars, and dry matter (DM) in conventional (average of three conventional treatments, CON-AV) and organic (ORG) treatments (mean \pm standard error); fold change indicates the change of ORG with respect to CON-AV (ORG/CON-AV) and p-value shows the statistical significance of the difference between CON-AV and ORG (significant $p$-values $<0.05$ are presented in bold). For each variable results of two way analysis of variance (F-statistics and $p$-values) of the factors treatment ( $\operatorname{Trm})$, year, and treatment by year interaction (Trm*Year) are also presented.

\begin{tabular}{|c|c|c|c|c|c|}
\hline Variable & Year & CON-AV & ORG & $\begin{array}{l}\text { Fold Change } \\
\qquad\left({ }^{*} 100 \%\right)\end{array}$ & $p$-Value \\
\hline \multirow{6}{*}{$\begin{array}{l}\text { Marketable } \\
\text { yield, } \mathrm{t} \mathrm{ha}^{-1}\end{array}$} & \multicolumn{5}{|c|}{ Trm: $\mathrm{F}_{1,40}=6.9, p=0.012 ;$ Year: $\mathrm{F}_{3,40}=94.8, p<0.001 ;$ Trm ${ }^{*}$ Year: $\mathrm{F}_{3,40}=0.9, p=0.442$} \\
\hline & 2011 & $6.3 \pm 1.2^{\mathrm{A}}$ & $8.2 \pm 0.8^{\mathrm{A}}$ & 130.5 & 0.380 \\
\hline & 2012 & $24.0 \pm 3.5^{\mathrm{B}}$ & $29.2 \pm 3.8^{B}$ & 121.6 & 0.020 \\
\hline & 2013 & $22.0 \pm 1.8^{B}$ & $25.7 \pm 3.8^{B}$ & 116.9 & 0.091 \\
\hline & 2014 & $25.8 \pm 4.9^{\mathrm{B}}$ & $26.3 \pm 3.8^{\mathrm{B}}$ & 102.0 & 0.818 \\
\hline & Average & $19.5 \pm 8.5$ & $22.4 \pm 9.1$ & 114.5 & 0.012 \\
\hline \multirow{6}{*}{$\begin{array}{c}\text { Percent of } \\
\text { discarded } \\
\text { yield, \% }\end{array}$} & \multicolumn{5}{|c|}{ Trm: $\mathrm{F}_{1,40}=5.6, p=0.023 ;$ Year: $\mathrm{F}_{3,40}=182.6, p<0.001 ; \operatorname{Trm}^{*}$ Year: $\mathrm{F}_{3,40}=4.5, p=0.008$} \\
\hline & 2011 & $68.0 \pm 5.5^{\mathrm{A}}$ & $65.1 \pm 3.3^{\mathrm{A}}$ & 95.7 & 0.419 \\
\hline & 2012 & $47.5 \pm 7.9^{\mathrm{B}}$ & $32.9 \pm 4.3^{B}$ & 69.2 & $<0.001$ \\
\hline & 2013 & $32.2 \pm 4.7^{C}$ & $30.0 \pm 4.4^{\mathrm{B}, \mathrm{C}}$ & 93.2 & 0.531 \\
\hline & 2014 & $18.1 \pm 3.4^{\mathrm{D}}$ & $21.2 \pm 2.2^{C}$ & 117.0 & 0.384 \\
\hline & Average & $41.5 \pm 19.5$ & $37.3 \pm 17.7$ & 90.0 & 0.023 \\
\hline \multirow{6}{*}{$\mathrm{N}, \%$} & \multicolumn{5}{|c|}{ Trm: $\mathrm{F}_{1,40}=0.1, p=0.707 ;$ Year: $\mathrm{F}_{3,40}=35.9, p<0.001 ;$ Trm ${ }^{*}$ Year: $\mathrm{F}_{3,40}=1.7, p=0.183$} \\
\hline & 2011 & $2.5 \pm 0.2^{\mathrm{A}}$ & $2.3 \pm 0.1^{A}$ & 94.0 & 0.260 \\
\hline & 2012 & $2.1 \pm 0.2^{B}$ & $2.1 \pm 0.1^{\mathrm{A}}$ & 99.1 & 0.840 \\
\hline & 2013 & $1.6 \pm 0.2^{C}$ & $1.6 \pm 0.1^{\mathrm{B}}$ & 101.3 & 0.891 \\
\hline & 2014 & $2.0 \pm 0.3^{B}$ & $2.3 \pm 0.2^{\mathrm{A}}$ & 113.0 & 0.056 \\
\hline & Average & $2.1 \pm 0.4$ & $2.1 \pm 0.3$ & 101.3 & 0.707 \\
\hline
\end{tabular}


Table 3. Cont.

\begin{tabular}{|c|c|c|c|c|c|}
\hline \multirow{6}{*}{$\begin{array}{c}\mathrm{NO}_{3 \prime} \\
\mathrm{mg} \mathrm{kg}^{-1}\end{array}$} & \multicolumn{5}{|c|}{ Trm: $\mathrm{F}_{1,40}=6.2, p=0.017 ;$ Year: $\mathrm{F}_{3,40}=181.2, p<0.001 ;$ Trm ${ }^{*}$ Year: $\mathrm{F}_{3,40}=2.3, p=0.088$} \\
\hline & 2011 & $283.3 \pm 36.7^{\mathrm{A}}$ & $292.3 \pm 10.6^{\mathrm{A}}$ & 103.2 & 0.603 \\
\hline & 2012 & $107.5 \pm 26.0^{B}$ & $99.7 \pm 4.2^{\mathrm{B}}$ & 92.7 & 0.650 \\
\hline & 2013 & $66.7 \pm 16.1^{C}$ & $24.6 \pm 5.4^{C}$ & 36.9 & 0.019 \\
\hline & 2014 & $194.4 \pm 27.9^{\mathrm{D}}$ & $150.0 \pm 29.3^{B}$ & 77.1 & 0.013 \\
\hline & Average & $163.0 \pm 88.6$ & $141.7 \pm 103.0$ & 86.9 & 0.017 \\
\hline \multirow{6}{*}{$\begin{array}{l}\text { Vitamin C, } \\
\text { mg } 100 \mathrm{~g}^{-1}\end{array}$} & \multicolumn{5}{|c|}{ Trm: $\mathrm{F}_{1,40}=5.3, p=0.026 ;$ Year: $\mathrm{F}_{3,40}=99.1, p<0.001 ;$ Trm ${ }^{*}$ Year: $\mathrm{F}_{3,40}=1.6, p=0.213$} \\
\hline & 2011 & $1.5 \pm 0.2^{\mathrm{A}}$ & $2.0 \pm 0.3^{\mathrm{A}}$ & 134.2 & 0.046 \\
\hline & 2012 & $2.7 \pm 0.1^{B}$ & $3.0 \pm 0.2^{B}$ & 113.5 & 0.168 \\
\hline & 2013 & $3.4 \pm 0.3^{C}$ & $3.2 \pm 0.4^{B}$ & 94.9 & 0.503 \\
\hline & 2014 & $4.1 \pm 0.7^{\mathrm{D}}$ & $4.6 \pm 0.0^{C}$ & 111.1 & 0.074 \\
\hline & Average & $2.9 \pm 1.1$ & $3.2 \pm 1.0$ & 110.0 & 0.026 \\
\hline \multirow{6}{*}{ Sugars, $\%$} & \multicolumn{5}{|c|}{ Trm: $\mathrm{F}_{1,40}=3.4, p=0.072 ;$ Year: $\mathrm{F}_{3,40}=14.7, p<0.001 ; \operatorname{Trm} *$ Year: $\mathrm{F}_{3,40}=3.8, p=0.018$} \\
\hline & 2011 & $6.4 \pm 0.7 \mathrm{~A}, \mathrm{~B}$ & $6.4 \pm 0.5^{\mathrm{A}}$ & 98.9 & 0.859 \\
\hline & 2012 & $5.8 \pm 0.5^{\mathrm{A}}$ & $5.9 \pm 0.5^{\mathrm{A}}$ & 102.1 & 0.763 \\
\hline & 2013 & $6.9 \pm 0.2^{B}$ & $8.5 \pm 0.0^{\mathrm{B}}$ & 122.3 & $<0.001$ \\
\hline & 2014 & $6.0 \pm 1.0^{\mathrm{A}}$ & $5.9 \pm 0.4^{\mathrm{A}}$ & 98.3 & 0.807 \\
\hline & Average & $6.3 \pm 0.8$ & $6.7 \pm 1.2$ & 105.9 & 0.072 \\
\hline \multirow{6}{*}{ Dry matter, \% } & \multicolumn{5}{|c|}{ Trm: $\mathrm{F}_{1,40}=0.4, p=0.512 ;$ Year: $\mathrm{F}_{3,40}=64.8, p<0.001 ; \operatorname{Trm} *$ Year: $\mathrm{F}_{3,40}=3.0, p=0.044$} \\
\hline & 2011 & $10.5 \pm 0.6^{\mathrm{A}}$ & $9.9 \pm 0.1^{\mathrm{A}}$ & 93.7 & 0.063 \\
\hline & 2012 & $10.4 \pm 0.5^{\mathrm{A}}$ & $11.0 \pm 0.4^{\mathrm{B}}$ & 106.5 & 0.058 \\
\hline & 2013 & $13.1 \pm 0.4^{B}$ & $12.6 \pm 0.3^{C}$ & 96.4 & 0.184 \\
\hline & 2014 & $10.9 \pm 0.7^{\mathrm{A}}$ & $10.8 \pm 0.1^{\mathrm{A}, \mathrm{B}}$ & 99.9 & 0.990 \\
\hline & Average & $11.2 \pm 1.2$ & $11.1 \pm 1.0$ & 99.0 & 0.512 \\
\hline
\end{tabular}

Mean values without common uppercase letters (A,B,C,D) within treatment (in columns) are statistically significantly different $(p<0.05$, Tukey-Kramer (HSD) test); Average = average of 2011-2014.

\subsection{Nitrogen and Nitrate}

The results of ANOVA showed that the carrot nitrogen content was not significantly affected by management system, whilst the opposite was true for nitrate content (Table 3). Both $\mathrm{N}$ and $\mathrm{NO}_{3}$ were significantly influenced by the trial year. The average $\mathrm{N}$ content across all trial years was equal for both CON-AV and ORG. N content was significantly lower in 2013 than in other trial years. Nitrate content was significantly lower in ORG than in CON-AV in two trial years out of four (2013 and 2014), and also remained significantly lower as an average across all years. When considering all four treatments separately, nitrate content was significantly higher in the drought year of 2011 than in the other trial years (Table S1).

\subsection{Vitamin C}

Vitamin C content in carrots varied statistically significantly depending on treatment and year (Supplementary Table S1), based on ANOVA analyses. Vitamin C content was significantly higher in ORG than in CON-AV as an average across all trial years (Table 3). However, the highest difference between cultivation systems was in the drought year of 2011 (34.2\%). At the same time, vitamin C content remained significantly lowest in all treatments in 2011, compared to other trial years (Table S1).

\subsection{Total Sugars}

According to the results of ANOVA, the total sugar content in the carrots was not influenced by treatment, but depended significantly on year, and treatment by year interaction (Table 3). Out of all trial years the average total sugar content was the highest in 2013 in both management systems, and the only significant difference between ORG and CON-AV appeared in this year (22.3\%). In spite of this, 
as an average of all trial years total sugar content did not differ significantly between management systems, nor between different conventional treatments (Table S1).

\subsection{Dry Matter}

The ANOVA results showed that carrot DM content was not influenced by treatment, but depended significantly on year, and treatment by year interaction (Table 3). The average DM content did not differ significantly between ORG and CON-AV across all trial years, nor were there any differences within single trial years. DM content was highest in 2013 in both management systems. When studying all four treatments separately it was evident that as an average across all trial years DM was slightly but significantly higher in CON1 than in other treatments (Table S1).

\subsection{Principal Component Analyses}

The first two principal components explained $80.5 \%$ of the total variance of the studied carrot yield and quality parameters. The strongest pattern (PC1 54.7\%) indicated that if the higher marketable yield was achieved, also the vitamin $C$ and DM content of carrots were higher, and the nitrogen and nitrate content, as well the discarded yield, were lower (Figure 1). These results are in accordance with the results of the correlation analysis (Table S2), where a significantly positive correlation was found between marketable yield and vitamin $C$ content $(r=0.58, p<0.001)$, as well as negative correlations between DM content and nitrogen and nitrate contents $(r=-0.59, p<0.001$ and $r=-0.61, p<0.001$, respectively), and between vitamin $C$ content and discarded yield $(r=-0.90, p<0.001)$.

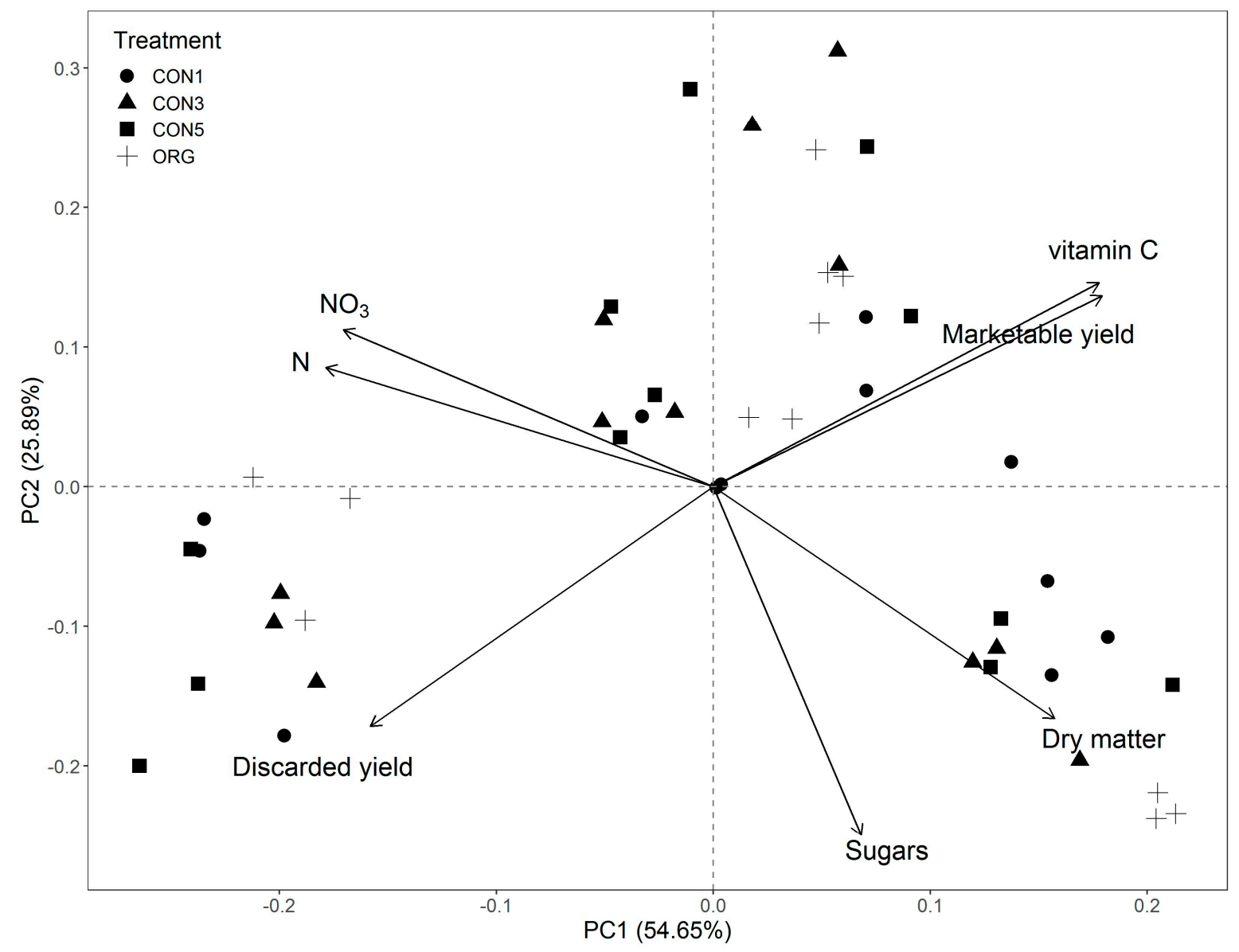

Figure 1. Biplot of principal component analysis by treatments. Vectors indicate the direction of increase of the carrot yield and quality parameters respective to the first two principal components; symbols distinguished by treatments mark the location of single samples in the PC1-PC2-plane. 
The second strongest pattern (PC2 25.9\%) mainly separates samples with higher and lower content of total sugars, where the samples with higher sugar content also tend to have higher DM content, and lower nitrogen and nitrate content. These results are also partly evident from the correlation analyses (Table S2), where there is a significant positive relationship between sugar content and DM $(r=0.53, p<0.001)$, and a significantly negative relationship between sugar and nitrogen content $(r=-0.30, p<0.05)$.

The analysis of principal component (PC) scores by treatment did not reveal any clear patterns (Figure 1), while PC scores by years showed clear between-year differences (Figure 2). In 2011 the samples had higher values of discarded yield, and lower values of marketable yield and vitamin $C$ content, while in 2013 the samples had the highest DM content, and samples from 2014 had the highest vitamin $\mathrm{C}$ content.

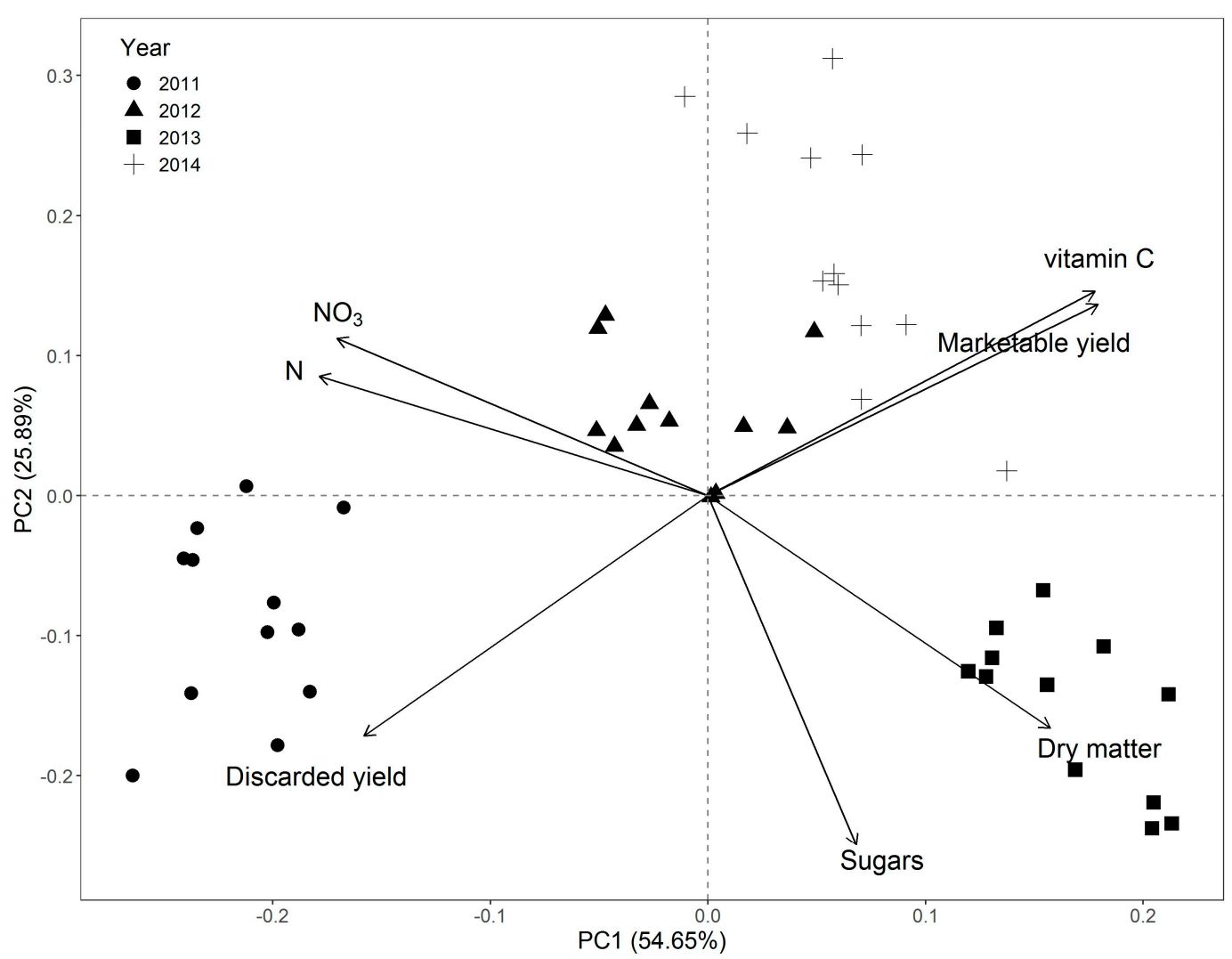

Figure 2. Biplot of principal component analysis by year. Vectors indicate the direction of increase of the carrot yield and quality parameters respective to the first two principal components; symbols distinguished by year mark the location of single samples in the PC1-PC2-plane.

\subsection{Pesticide Residues}

Out of the four analyzed pesticides, residues of three (aclonifen, chlorothalonil, and cypermethrin) were detected in all trial years except 2012 (Table 4). Residues of the herbicide (propaquizafop) were not detected in any of the trial years. The fungicide chlorothalonil was detected in CON5 in three years and in CON3 only in 2013, although it was applied in these treatments in each trial year. The herbicide aclonifen was detected in two treatments out of three; in CON5 in two years and in CON1 only in 2011. The insecticide cypermethrin was found only in CON5 in 2014, despite being used in two treatments in each trial year. The content of all detected residues was below the allowed maximum residue levels (aclonifen 0.08; propaquizafop 0.2; cypermethrin 0.05 ; chlorothalonil $0.3 \mathrm{mg} \mathrm{kg}^{-1}$ ) by the EC Regulation No 396/2005 [38]. No pesticide residues were found in the organic carrots. 
Table 4. Pesticide active substances, found in conventionally produced carrots.

\begin{tabular}{|c|c|c|c|c|c|c|c|}
\hline \multirow[b]{2}{*}{ Treatment } & \multirow{2}{*}{$\begin{array}{c}\text { Used } \\
\text { Pesticides a.s. }\end{array}$} & \multicolumn{2}{|c|}{2011} & \multicolumn{2}{|c|}{2013} & \multicolumn{2}{|c|}{2014} \\
\hline & & $\begin{array}{l}\text { Pesticide } \\
\text { Residue }\end{array}$ & $\begin{array}{l}\text { Content, } \\
\mathrm{mg} \mathrm{kg}^{-1}\end{array}$ & $\begin{array}{l}\text { Pesticide } \\
\text { Residue }\end{array}$ & $\begin{array}{l}\text { Content, } \\
\text { mg kg-1 }^{-1}\end{array}$ & $\begin{array}{l}\text { Pesticide } \\
\text { Residue }\end{array}$ & $\begin{array}{l}\text { Content, } \\
\mathrm{mg} \mathrm{kg}^{-1}\end{array}$ \\
\hline CON5 & $\begin{array}{l}\text { aclonifen } \\
\text { propaqui. } \\
\text { cyperm. } \\
\text { chlorot. }\end{array}$ & $\begin{array}{l}\text { aclonifen } \\
\text { chlorot. }\end{array}$ & $\begin{array}{l}<0.01 \\
0.013\end{array}$ & chlorot. & 0.223 & $\begin{array}{l}\text { aclonifen } \\
\text { cyperm. } \\
\text { chlorot. }\end{array}$ & $\begin{array}{l}0.008 \\
0.028 \\
0.007\end{array}$ \\
\hline CON3 & $\begin{array}{l}\text { aclonifen } \\
\text { cyperm. } \\
\text { chlorot. }\end{array}$ & $\begin{array}{l}\text { No } \\
\text { residues }\end{array}$ & $\begin{array}{l}\text { No } \\
\text { residues }\end{array}$ & chlorot. & 0.080 & aclonifen & $<0.01$ \\
\hline CON1 & aclonifen & aclonifen & $<0.01$ & - & - & - & - \\
\hline
\end{tabular}

a.s. = active substances; propaqui. = propaquizafop; cyperm. = cypermethrin; chlorot. = chlorothalonil; "-" No analyses have been performed.

\section{Discussion}

The results of our study show that organic management can have an advantage over the conventional system in both yield and quality of carrots at equal $\mathrm{N}$ levels. In particular, we found higher marketable and lower discarded yield, and better quality characteristics of carrots (lower nitrate and higher vitamin $C$ content), in organic compared to conventional management. For a few quality characteristics (nitrogen, total sugar, and DM content) there were no convincing differences between the management treatments of carrots. In addition, carrots from organic management were free of pesticide residues, whereas several residues were found in carrots from conventional management.

Contrary to expectations we found that organically grown carrots had on average $14.5 \%$ higher yield and $10 \%$ lower discarded yield compared to conventionally grown carrots. Previous research comparing organic and conventional vegetable productions have found up to $33 \%$ lower yields from organic production $[15,16]$. One of the main factors limiting organic yield has typically been lower nutrient availability, while fertilization rates are higher in conventional systems [39]. One important reason for higher yield of organically grown carrots in our experiment was the fact that in the ORG treatment we applied compost with a $\mathrm{N}$ rate equal to that in the conventional treatments. Organic fertilizer is known to have advantages over mineral fertilizers since it increases total organic carbon content, soil organic matter, stimulates the activity of microorganisms, and increases enzymatic activity in soil, and thus increases the availability of nutrients for the plants [14,32,40-42].

Another important factor influencing crop yield is the prevailing weather during the growing period. Lotter et al. [43] found that under severe drought conditions organically managed farms produced higher yields than their conventional counterparts. This could be explained by increased organic matter level in soil making the organic farming system less susceptible to extreme drought events [42]. In our case, there was a shortage of precipitation in three trial years out of four, and the results overall followed the above-mentioned tendency towards higher yield in organic management compared to conventional. However, our results showed that significantly higher yields with organic management appeared when the weather conditions were more favorable for carrot production, as in 2012. This was also accompanied by significantly lower discarded yield in the ORG treatment. In contrast, the highest discarded yield was found in the drought year of 2011. This is in accordance with Thorup-Kristensen et al. [44], who found that the highest percentage of discarded yield in both organic and conventional production systems was produced in the year with the lowest amount of precipitation. However, in contrast to our experiment, the study by Thorup-Kristensen et al. [44] did not reveal a management effect on the discarded yield of carrot.

In our experiment the discarded yield in all treatments was formed mostly due to physiological disorders of carrots. Notably, there was a low pressure of insects and diseases due to the lack of other carrot production fields in the neighboring area, from where carrot damaging pests and diseases could have been transmitted to the trial. Another reason for the low occurrence of carrot pests 
and diseases might be due to the use of old local variety "Jõgeva Nantes", which according to our previous experience has been disease-free even without the use of fungicides (I. Bender, pers. obs.). Old varieties can be genetically heterogeneous and might have specific adaptation traits relevant for organic conditions [45-47]. This could also explain why application of pesticides and fungicides in the CON treatments did not result in lower discarded yield than in the ORG.

Nitrogen content in the carrots did not differ between management treatments. According to some previous studies, significantly higher concentration of nitrogen was detected in conventional carrots than in organic, which can be explained by lower $\mathrm{N}$ fertilization rates in the organic system [48-50]. In our experiment, the lack of differences in $\mathrm{N}$ content is likely a result of applying fertilization, so that $\mathrm{N}$ levels were equal in the two treatments. However, there was a significant year effect on the $\mathrm{N}$ content of carrots, being lower in 2013 than in other trial years, probably caused by shortage of precipitation in June-September. Nitrate content on the other hand was significantly influenced both by treatment and year, being lower in the ORG than in the CON-AV treatment, and highly variable across all trial years. The nitrate content of the carrots was highest in the extremely dry 2011. Some earlier studies have also shown that organic carrots contain less nitrate than conventional carrots [24,48,49,51,52], and that the year of production can have a significant effect [53]. Gennaro and Quaglia [54] concluded in their review, that lower nitrate levels in organic vegetables seem to be due to differences in $\mathrm{N}$ fertilization level. However, we found lower nitrate content in ORG at equal $\mathrm{N}$ fertilization levels in both systems. Mineral fertilizer used in CON treatments directly provides nitrate, while compost is slowly decomposable and nitrogen releases gradually [55]. In general, carrot is classified as a vegetable with a low nitrate content, with the average being $200-500 \mathrm{mg} \mathrm{kg}^{-1}$ [56]. The content of nitrate in our experiment was even lower, except in 2011.

We found that as an average of all trial years, carrots in ORG had significantly higher vitamin $C$ content compared to CON-AV, being as much as $34 \%$ higher in the drought year of 2011. This is in line with previous research, reporting higher vitamin $C$ content in vegetables in organic production [57-60]. However, a few studies have found no differences in vitamin $C$ content between these management systems for carrots and other vegetables [25,61]. Vitamin C content in vegetables depends on several factors, such as genotype, maturity at harvest, fertilizer type, pre-harvest weather conditions, and soil type [62,63]. As all mentioned factors except fertilizer type were the same in our study for carrots in CON and ORG treatments, we assume that the differences in the content of vitamin C could have been due to different fertilizer type; compost was used in the organic, whereas mineral fertilizer was used in the conventional treatments.

The management system in our study did not influence the total sugar content in carrots, except in 2013, where significantly more sugars were found in ORG compared to CON-AV. Some earlier studies have similarly found that the production method did not affect the total sugar content in carrots $[48,49,64]$. However, several studies have concluded that organic vegetables, including carrots, contain more sugars than conventional ones [58,65-68]. Total sugar content in carrots could be affected more by climate-related factors than by management methods [69]. Bach et al. [64] found that higher temperatures, in particular, resulted in higher total sugar content. Indeed, the total sugar content of carrots in our trial was up to $8.5 \%$, in the warmer than LTA year of 2013, whereas for the variety "Jógeva Nantes" the sugar content is typically between 6.5-7.5\% (unpublished data).

According to our results DM content did not differ significantly between organic and conventional carrots, which is in accordance with earlier studies $[48,57,64,67]$, but contradict others which have reported higher DM content in organically cultivated carrots than in conventional carrots $[49,52,61,65,66]$. However, DM in our trial was influenced by the weather conditions of the trial years, being significantly higher in both management systems in the warmer than LTA year of 2013 than in the other trial years. These results indicate that the effect of weather conditions on DM overshadowed that of cultivation methods.

We found no pesticide residues in organic carrots, whereas residues of three out of four of the pesticides used were detected in the conventional carrots. In general organic food is reported to contain 
fewer or no residues [20,70-73]. In the summer of 2012, the amount of precipitation during the main spraying period was high, and therefore the chemical control measures were not successful which resulted in the absence of pesticide residues in carrot samples. Chlorothalonil and aclonifen were the most frequently detected pesticide residues in conventional carrots. Chlorothalonil is a broad-spectrum fungicide with low aqueous solubility. This residue has often been found in conventionally grown vegetables [74-78]. The substance group of systemic and selective herbicide aclonifen is not highly soluble in water, but is in many organic solvents, being moderately persistent in soil [79]. Persistence of the insecticide cypermethrin in the environment varies from 14.6 to 76.2 days (half-life), depending on the physicochemical properties of the soil [80]. Cypermethrin was detected only once in our carrot samples. Nevertheless, pesticide residues detected in conventional carrots might pose a threat to the environment and consumers. Even legislatively determined "safe" levels of residues, in case of simultaneous exposure of multiple chemical substances, may have synergistic effects, causing unknown adverse health issues [81].

\section{Conclusions}

The results of our four-year comparison of organic and conventional carrot production show that organic management can have advantages over the conventional system in both yield and quality, at equal $\mathrm{N}$ fertilization level. In particular, we found a higher marketable yield, lower discarded yield, and higher quality of carrots (lower nitrate and higher vitamin C content) in organic compared to conventional management. This can be explained by the higher quality of organic compost compared to the mineral fertilizer. Besides treatment effects, these variables were also influenced by the weather conditions of the trial years. Our study suggests that organic management of carrots can exceed conventional management in yield and quality, when $\mathrm{N}$ fertilization levels are equivalent.

Supplementary Materials: The following are available online at http://www.mdpi.com/2073-4395/10/9/1420/s1, Table S1: Marketable and discarded yield and content of nitrogen, nitrates, vitamin C, sugars and dry matter (mean \pm standard error) in conventional (CON5, CON3, CON1) and organic (ORG) treatments from 2011 to 2014 For each variable results of two way analysis of variance (F-statistics and p-values of factors treatment (Trm), year and treatment by year interaction (Trm*Year)) are presented; Table S2: Spearman rank correlation coefficients between studied carrot yield and quality parameters.

Author Contributions: Conceptualization, I.B. and A.L.; methodology, I.B. and A.L.; software, T.K.; validation, I.B., I.H., A.I. and I.T.; formal analysis, I.B., L.E. and T.K.; investigation, I.B.; resources, I.B. and A.L.; data curation, I.B., L.E. and H.K.; writing-original draft preparation, I.B., I.H., A.I. and I.T.; writing-review and editing, I.B., I.H., A.I. and I.T.; visualization, T.K. and T.T.; supervision, A.L. and I.T.; project administration, I.B. and I.T.; funding acquisition, A.L. and I.T. All authors have read and agreed to the published version of the manuscript.

Funding: This research was supported by the Personal Research Grant (PUT1170) of the Estonian Ministry of Education and contracts 8-2/T1003PKAI of the Estonian Ministry of Rural Affairs.

Acknowledgments: The authors would like to thank Ingrid Williams for the language correction and Sirje Tamm, Ülle Ratassepp, Taavi Piiskoppel, Larissa Sirel, Siiri Margens for their excellent technical assistance.

Conflicts of Interest: The authors declare no conflict of interest.

\section{References}

1. IFOAM. Consolidated Annual Report of IFOAM-Organics International; IFOAM: Bonn, Germany, 2018.

2. Seufert, V.; Ramankutty, N. Many shades of gray-The context-dependent performance of organic agriculture. Sci. Adv. 2017, 3, e1602638. [CrossRef] [PubMed]

3. Niggli, U. Sustainability of organic food production: Challenges and innovations. Proc. Nutr. Soc. 2015, 74, 83-88. [CrossRef] [PubMed]

4. Apaolaza, V.; Hartmann, P.; D’Souza, C.; López, C.M. Eat organic-Feel good? The relationship between organic food consumption, health concern and subjective wellbeing. Food Qual. Prefer. 2018, 63, 51-62. [CrossRef] 
5. Ditlevsen, K.; Sandøe, P.; Lassen, J. Healthy food is nutritious, but organic food is healthy because it is pure: The negotiation of healthy food choices by Danish consumers of organic food. Food Qual. Prefer. 2019, 71, 46-53. [CrossRef]

6. European Comission. Organic farming in EU. A fast growing sector. EU Agric. Markets. Briefs $2019,13$. Available online: https://ec.europa.eu/info/sites/info/files/food-farming-fisheries/farming/documents/marketbrief-organic-farming-in-the-eu_mar2019_en.pdf (accessed on 16 September 2020).

7. Tuomisto, H.; Hodge, I.; Riordan, P.; Macdonald, D. Does organic farming reduce environmental impacts? A meta-analysis of European research. J. Environ. Manag. 2012, 112, 309-320. [CrossRef]

8. Orsini, F.; Maggio, A.; Rouphael, Y.; de Pascale, S. "Physiological quality” of organically grown vegetables. Sci. Hortic. 2016, 208, 131-139. [CrossRef]

9. Willer, H.; Lernoud, J. Vegetables. In The World of Organic Agriculture; Willer, H., Lernoud, J., Eds.; FiBL \& IFOAM—Organics International: Frick, Switzerland, 2019; pp. 125-128.

10. Connor, D.J. Organic agriculture cannot feed the world. Field Crop Res. 2008, 106, 187-190. [CrossRef]

11. Ponisio, L.C.; M'Gonigle, L.K.; Mace, K.C.; Palomino, J.; de Valpine, P.; Kremen, C. Diversification practices reduce organic to conventional yield gap. Proc. R. Soc. B Biol. Sci. 2014, 282, 1396. [CrossRef]

12. Kniss, R.K.; Savage, S.D.; Jabbour, R. Commercial crop yields reveal strengths and weaknesses for organic agriculture in the United States. PLoS ONE 2016, 11, e0161673. [CrossRef]

13. Reganold, J.P.; Wachter, J.M. Organic agriculture in the twenty-first century. Nat. Plants 2016, 2, 5221. [CrossRef] [PubMed]

14. Lesur-Dumoulin, C.; Malézieux, E.; Ben-Ari, T.; Langlais, C.; Makowski, D. Lower average yields but similar yield variability in organic versus conventional horticulture. A meta-analysis. Agron. Sustain. Dev. 2017, 37, 45. [CrossRef]

15. De Ponti, T.; Rijk, B.; van Ittersum, M.K. The crop yield gap between organic and conventional agriculture. Agric. Syst. 2012, 108, 1-9. [CrossRef]

16. Seufert, V.; Ramankutty, N.; Foley, J.A. Comparing the yields of organic and conventional agriculture. Nature 2012, 485, 229-234. [CrossRef] [PubMed]

17. Smith, O.M.; Cohen, A.L.; Rieser, C.J.; Davis, A.G.; Taylor, J.M.; Adesanya, A.W.; Jones, M.S.; Meier, A.R.; Reganold, J.P.; Orpet, R.J.; et al. Organic farming provides reliable environmental benefits but increases variability in crop yields: A global meta-analysis. Front. Sustain. Food Syst. 2019, 3, 82. [CrossRef]

18. WHO. Pesticide Residues in Food (19 February 2018). Available online: https://www.who.int/news-room/ fact-sheets/detail/pesticide-residues-in-food (accessed on 29 July 2020).

19. Silva, V.; Mol, H.G.J.; Zomer, P.; Tienstra, M.; Ritsema, C.J.; Geissen, V. Pesticide residues in European agricultural soils-A hidden reality unfolded. Sci. Total Environ. 2019, 653, 1532-1545. [CrossRef]

20. Gomiero, T. Food quality assessment in organic vs. conventional agricultural produce: Finding and issues. Appl. Soil Ecol. 2018, 123, 714-728. [CrossRef]

21. Seljåsen, R.; Kristensen, H.L.; Kretzschmar, U.; Birlouez-Aragon, I.; Paoletti, F.; Lauridsen, C.; Wyss, G.S.; Busscher, N.; Mengheri, E.; Sinesio, F.; et al. How to understand the complexity of product quality and the challenges in differentiating between organically and conventionally grown products-Exemplified by fresh and heat-processed carrots (Daucus carota L.). Org. Agric. 2016, 6, 31-47. [CrossRef]

22. EFSA (European Food Safety Authority). Opinion of the Scientific Panel on Contaminants in the Food chain on a request from the European Commission to perform a scientific risk assessment on nitrate in vegetables. EFSA J. 2008, 6, 689. [CrossRef]

23. Jørgensen, H.; Bach Knudsen, K.E.; Lauridsen, C. Influence of different cultivation methods on carbohydrate and composition and digestibility of energy of fruits and vegetables. J. Sci. Food Agric. 2012, 92, 2876-2882. [CrossRef]

24. Seljåsen, R.; Kristensen, H.L.; Lauridsen, C.; Wyss, G.S.; Kretzschmar, U.; Birlouez-Aragone, I.; Kahl, J. Quality of carrots as affected by pre- and postharvest factors and processing. J. Sci. Food. Agric. 2013, 93, 2611-2626. [CrossRef] [PubMed]

25. Fjelkner-Modig, S.; Bengtsson, H.; Stegmark, R.; Nyström, S. The influence of organic and integrated production on nutritional, sensory and agricultural aspects of vegetable raw materials for food production. Acta Agric. Scand. Sect. B Plant Soil Sci. 2000, 50, 102-113. [CrossRef]

26. Dangour, A.D.; Dodhia, S.K.; Hayter, A.; Allen, E.; Lock, K.; Uauy, R. Nutritional quality of organic foods: A systematic review. Am. J. Clin. Nutr. 2009, 90, 680-685. [CrossRef] [PubMed] 
27. Bernacchia, R.; Preti, R.; Vinci, G. Organic and conventional foods: Differences in nutrients. Ital. J. Food Sci. 2016, 28, 565-578.

28. EPRS (European Parliamentary Research Service). Human Health Implications of Organic Food and Organic Agriculture. 2016. Available online: https://www.europarl.europa.eu/RegData/etudes/STUD/2016/581922/ EPRS_STU(2016)581922_EN.pdf (accessed on 29 July 2020).

29. Reeve, J.R.; Hoagland, L.A.; Villalba, J.J.; Carr, P.M.; Atucha, A.; Cambardella, C.; Davis, D.R.; Delate, K. Organic farming, soil health, and food quality: Considering possible links. In Advances in Agronomy, 137; Sparks, D.L., Ed.; Academic Press: Chennai, India, 2016; Volume 137, pp. 319-368. [CrossRef]

30. Tejada, M.; Gonzalez, J.L.; García-Martínez, A.M.; Parrado, J. Application of a green manure composted with beet vinasse on soil restoration: Effects on soil properties. Bioresour. Technol. 2008, 99, 4949-4957. [CrossRef]

31. Diacono, M.; Montemurro, F. Long-term effects of organic amendments on soil fertility. A review. Agron. Sustain. Dev. 2010, 30, 401-422. [CrossRef]

32. Bai, Z.; Caspari, T.; Gonzalez, M.R.; Batjes, N.H.; Mäder, P.; Bünemann, E.K.; de Goede, R.; Brussard, L.; Minggang, X.; Ferreira, C.S.S.; et al. Effects of agricultural management practices on soil quality: A review of long-term experiments for Europe and China. Agric. Ecosyst. Environ. 2018, 265, 1-7. [CrossRef]

33. Kirchmann, H.; Kätterer, T.; Bergström, L.; Börjesson, G.; Bolinder, M.A. Flaws and criteria for design and evaluation of comparative organic and conventional cropping systems. Field Crop Res. 2016, 186, 99-106. [CrossRef]

34. Metzger, M.J.; Bunce, R.G.; Jongman, R.H.; Mücher, C.A.; Watkins, J.W. A climatic stratification of the environment of Europe. Glob. Ecol. Biogeogr. 2005, 14, 549-563. [CrossRef]

35. FAO. World Reference Base for Soil Resources 2014. International Soil Classification System for Naming Soils and Creating Legends for Soil Maps World Soil Resources; Report 106; FAO: Rome, Italy, 2015. Available online: http://www.fao.org/3/a-i3794en.pdf (accessed on 16 September 2020).

36. Meier, U. Growth Stages of Mono- and Dicotyledonous Plants. BBCH Monograph; Open Agrar Repositorium: Quedlinburg, Germany, 2018. [CrossRef]

37. Turbas, E.; Oll, Ü. Agrokeemia Laboratoorne Praktikum [Practical Analyses of Agrochemistry]; Valgus: Tallinn, Estonia, 1969.

38. Regulation (EC) No 396/2005. Available online: https://ec.europa.eu/food/plant/pesticides/eu-pesticidesdatabase (accessed on 14 September 2020).

39. Kirchmann, H.; Bergström, L.; Kätterer, T.; Andrén, O.; Andersson, R. Can organic crop production feed the world. In Organic Crop Production-Ambitions and Limitations; Kirchmann, H., Bergström, L., Eds.; Springer: Dordrecht, The Netherlands, 2008; pp. 39-72.

40. Henneron, L.; Bernard, L.; Hedde, M.; Pelosi, C.; Villenave, C.; Bertrand, M.; Girardin, C.; Blanchart, E. Fourteen years of evidence for positive effects of conservation agriculture and organic farming on soil life. Agron. Sustain. Dev. 2015, 35, 169-181. [CrossRef]

41. Tian, J.; Lou, Y.; Fang, H.; Liu, S.; Xu, M.; Blagodatskaya, E.; Kuzyakov, Y. Response of soil organic matter fractions and composition of microbial community to long-term organic and mineral fertilization. Biol. Fertil. Soils 2017, 53, 523-532. [CrossRef]

42. Scharma, M.; de Haan, J.J.; Kroonen, M.; Verstegen, H.; van der Putten, W.H. Crop yield cap and stability in organic and conventional farming system. Agric. Ecosyst. Environ. 2018, 256, 123-130. [CrossRef]

43. Lotter, D.W.; Seidel, R.; Liebhardt, W. The performance of organic and conventional cropping systems in an extreme climate year. Am. J. Altern. Agric. 2003, 18, 146-154. [CrossRef]

44. Thorup-Kristensen, K.; Dresbøll, D.B.; Kristensen, H.L. Crop yield, root growth, and nutrient dynamics in a conventional and three organic cropping systems with different levels of external inputs and $\mathrm{N}$ re-cycling through fertility building crops. Eur. J. Argon. 2012, 37, 66-82. [CrossRef]

45. Finckh, M.R. Integration of breeding and technology into diversification strategies for disease control in modern agriculture. Eur. J. Plant Pathol. 2008, 121, 399-409. [CrossRef]

46. Dawson, J.C.; Murphy, K.M.; Huggins, D.R.; Jones, S.S. Evaluation of winter wheat breeding lines for traits related to nitrogen use under organic management. Org. Agric. 2011, 1, 65-80. [CrossRef]

47. Cortés-Olmos, C.; Leiva-Brondo, M.; Roselló, J.; Raigón, D.M.; Cebolla-Cornejo, J. The role of traditional varieties of tomato as sources of functional compounds. J. Sci. Food Agric. 2014, 94, 2888-2904. [CrossRef]

48. Bender, I.; Ess, M.; Matt, D.; Moor, U.; Tõnutare, T.; Luik, A. Quality of organic and conventional carrots. Agron. Res. 2009, 7, 572-577. 
49. Bender, I.; Moor, U.; Luik, A. The effect of growing systems on the quality of carrots. Res. Rural Dev. 2015, 1, 118-123.

50. Søltoft, M.; Nielsen, J.; Holst Laursen, K.; Husted, S.; Halekoh, U.; Knuthsen, P. Effects of organic and conventional growth systems on the content of flavonoids in onions and phenolic acids in carrots and potatoes. J. Agric. Food Chem. 2010, 58, 10323-10329. [CrossRef]

51. Pussemier, L.; Larondelle, Y.; Pethegem, C.; Huyghebaert, A. Chemical safety of conventionally and organically produced foodstuffs: A tentative comparison under Belgian conditions. Food Control 2006, 17, 14-21. [CrossRef]

52. Lairon, D. Nutritional quality and safety of organic food. A review. Agron. Sustain. Dev. 2009, 30, $33-41$. [CrossRef]

53. Ilić, Z.S.; Šunić, L. Nitrate content of root vegetables during different storage conditions. Acta Hortic. 2015, 1079, 659-665. [CrossRef]

54. Gennaro, L.; Quaglia, G.B. Food safety and nutritional quality of organic vegetables. Acta Hortic. 2003, 614, 675-680. [CrossRef]

55. Matallana González, M.C.; Martínez-Tome, M.J.; Torija Isasa, M.E. Nitrate and nitrite content in organically cultivated vegetables. Food Addit. Contam. B 2010, 3, 19-29. [CrossRef]

56. Santamaria, P. Nitrate in vegetables: Toxicity, content, intake and EC Regulation. J. Sci. Food Agric. 2006, 86, 10-17. [CrossRef]

57. Brandt, K.; Leifert, C.; Sanderson, R.; Seal, C.J. Agroecosystem management and nutritional quality of plant foods: The case of organic fruits and vegetables. Crit. Rev. Plant Sci. 2011, 30, 177-179. [CrossRef]

58. Hallmann, E. The influence of organic and conventional cultivation systems on the nutritional value and content of bioactive compounds in selected tomato types. J. Sci. Food Agric. 2012, 92, 2840-2848. [CrossRef]

59. Oliveira, A.B.; Moura, C.F.H.; Gomes-Filho, E.; Marco, C.A.; Urban, L.; Miranda, M.R.A. The impact of organic farming on quality of tomatoes is associated to increased oxidative stress during fruit development. PLoS ONE 2013, 8, e56354. [CrossRef]

60. Vinha, A.F.; Barreira, S.V.P.; Costa, A.S.G.; Alves, R.C.; Oliveira, M.B.P.P. Organic versus conventional tomatoes: Influence on physicochemical parameters, bioactive compounds and sensorial attributes. Food Chem. Toxicol. 2014, 67, 139-144. [CrossRef]

61. Bender, I.; Ingver, A. The influence of production methods on yield and quality of carrots and swedes. Acta Hortic. 2012, 960, 293-298. [CrossRef]

62. Mozafar, A. Plant Vitamins: Agronomic, Physiological and Nutritional Aspects; CRC Press: Boca Raton, FL, USA, 1994.

63. Lee, S.K.; Kader, A.A. Preharvest and postharvest factors influencing vitamin C content of horticultural crops. Postharvest Biol. Technol. 2000, 20, 207-220. [CrossRef]

64. Bach, V.; Kidmose, U.; Kristensen, H.L.; Edelenbos, M. Eating quality of carrots (Daucus carota L.) growing in one conventional and three organic cropping systems over three years. J. Agric. Food Chem. 2015, 63, 9803-9811. [CrossRef] [PubMed]

65. Rembiałkovska, E.; Hallmann, E. Influence of cultivation method (organic vs. conventional) on selected quality attributes of carrots (Daucus carota). Zyvienie Czovieka Metab. 2007, 34, 550-556.

66. Rembiałkovska, E.; Średnicka, D. Organic food quality and impact on human health. Agron. Res. 2009, 7, 719-727.

67. Gastoł, M.; Domagała-Świątkiewicz, I.; Krośniak, M. Organic versus conventional—A comparative study on quality and nutritional value of fruit and vegetable juices. Biol. Agric. Hortic. 2011, 27, 310-319. [CrossRef]

68. Pereira, F.O.; Pereira, R.S.; Rosa, L.S.; Teodoro, A.J. Organic and conventional vegetables: Comparison of the physical and chemical characteristics and antioxidant activity. Afr. J. Boitechnol. 2016, 15, 1746-1755. [CrossRef]

69. Rosenfeld, H.J.; Samuelsen, R.T.; Lea, P. Relationship between physical and chemical characteristics of carrots grown at northern latitudes. J. Hortic. Sci. Biotechnol. 1998, 73, 65-73. [CrossRef]

70. Hoogenboom, L.A.P.; Bokhorst, J.G.; Northolt, D.M.; van de Vijver, L.P.L.; Broex, N.J.G.; Mevius, D.J.; Meijs, J.A.C.; van der Roest, J. Contaminants and microorganisms in Dutch organic food products: A comparison with conventional products. Food Addit. Contam. Part A 2008, 25, 1195-1207. [CrossRef]

71. Lima, G.P.P.; Vianello, F. Review on the main differences between organic and conventional plant-based foods. Int. J. Food Sci. Technol. 2011, 46, 1-13. [CrossRef] 
72. Barański, M.; Średnicka-Tober, D.; Volakakis, N.; Seal, C.; Sanderson, R.; Stewart, G.B.; Benbrook, C.; Biavati, B.; Markellou, E.; Giotis, C.; et al. Higher antioxidant and lower cadmium concentration and lower incidence of pesticide residues in organically grown crops: A systematic literature review and meta-analyses. Br. J. Nutr. 2014, 5, 794-811. [CrossRef] [PubMed]

73. EFSA (European Food Safety Authority). The 2017 European Union report on pesticide residues in food. EFSA J. 2019, 17. [CrossRef]

74. Yuan, Y.; Chen, C.; Zheng, C.; Wang, X.; Yang, G.; Wang, Q.; Zhang, Z. Residue of chlorpyrifos and cypermethrin in vegetables and probabilistic exposure assessment for consumers in Zhejiang Province, China. Food Control 2014, 36, 63-68. [CrossRef]

75. Ahoudi, H.; Gnandi, K.; Tanouayi, G.; Ouro-Sama, K.; Yorke, J.; Creppy, E.; Moesch, C. Assessment of pesticides residues contents in the vegetables cultivated in urban area of Lome (southern Togo) and their risks on public health and the environment Togo. Int. J. Biol. Chem. Sci. 2018, 12, 2172-2185. [CrossRef]

76. Divakara, J.; Sharma, D. Dissipation of chlorothalonil in leafy vegetables accelerated by use of biofertilizer. Pest Manag. Hortic. Ecosyst. 2019, 25, 109-115.

77. U.S. Food and Drug Administration. Pesticide Residue Monitoring Program. Fiscal year 2017 Pesticide Report. FDA Pesticide Residue Monitoring Program Reports and Data; 2019. Available online: www.fda. gov/food/pesticides/pesticide-residue-monitoring-2017-report-and-data (accessed on 29 July 2020).

78. Office of Environmental Health Hazard Assessment. Proposition 65. Interpretive Consumption of Chlorothalonil Residues in Certain Foods. Interpretive Guidelines No. 2019-01-2019-09; 2019. Available online: Oehha.ca.gov/media/downloads/crnr/chlorothalonilig111519.pdf (accessed on 29 July 2020).

79. Onder Erguven, G.; Byhan, H.; Demir, G.; Ikizoglu, B.; Kanat, G. Monitoring aclonifen remediation in soil with a laboratory-scale research. J. Chem. 2016. [CrossRef]

80. Chen, S.; Geng, P.; Xiao, Y.; Hu, M. Bioremediation of $\beta$-cypermethrin and 3-phenoxybenzaldehyde contaminated soils using Streptomyces aureus HP-S-01. Appl. Microbiol. Biotechnol. 2012, 94, 505-515. [CrossRef]

81. Nicolopoulou-Stamati, P.; Maipas, S.; Kotampasi, C.; Stamatis, P.; Hens, L. Chemical pesticides and human health: The urgent need for a new concept in agriculture. Front. Public Health 2016, 4. [CrossRef]

(C) 2020 by the authors. Licensee MDPI, Basel, Switzerland. This article is an open access article distributed under the terms and conditions of the Creative Commons Attribution (CC BY) license (http://creativecommons.org/licenses/by/4.0/). 